\title{
Effect of High Doses of Omega-3 Fatty Acids on the Metabolism of Bones in Adult Females Rats
}

\author{
Hadeel M. Al-Hashemi Elham M. Al-Khashab Ameira A. Hamdoon \\ Department of Physiology Biochemistry and Pharmacology \\ College of Veterinary Medicine \\ University of Mosul
}

(Received 9/9/2012;Accepted 7/11/2012)

\begin{abstract}
This study was done to examine the effect of higher doses of omega-3 fatty acids on bones metabolism because most studies that proved the importance of omega- 3 didn't limit the appropriate dose and didn't study the side effects of high doses especially on bone.

Twenty female rats whose ages (2.5-3) months and initially weighing (220-300) gm, were divided in to four groups and given 200,400 or $600 \mathrm{mg} / \mathrm{kg}$ orally of omega-3 fatty acids for 30 days. At the end of the experiments, the blood was withdrawn, the right femur was taken to determine the percentage of calcium, phosphorus and magnesium and the left femur for hacking histological. The results showed that $200 \mathrm{mg} / \mathrm{kg}$ omega-3 lead to a significant decrease in ALP activity with an elevation in $\mathrm{Ca}$ and $\mathrm{P}$ in serum and a significant reduction in percentage of $\mathrm{Ca}$ and $\mathrm{P}$ with elevation in percentage $\mathrm{Mg}$ in bone ash, while the activity of ALP was significantly elevated in the rats that treated with $400 \mathrm{mg} / \mathrm{kg}$ omega-3fatty acids accompanied with elevation in serum $\mathrm{Ca}$ and $\mathrm{P}$ and reduction in percentage of $\mathrm{Ca}$ and elevation in percentage of $\mathrm{P}$ in bone ash compared with control group. Treatment 600 $\mathrm{mg} / \mathrm{kg}$ omega-3 lead to elevation in ALP activity and reduction in Ca and P in serum and bone ash. Histological results showed the appearance of osteoblasts and osteocytes and low number of osteoclasts with $200 \mathrm{mg} / \mathrm{kg}$ omega-3, while the treatment of rats with 400 and 600 $\mathrm{mg} / \mathrm{kg}$ omega-3 lead to reduce the number of osteoblasts and the appearance of osteoclasts and osteocytes. These findings provide evidence that higher doses of omega-3 supplementation can lead to bone resorption and imbalance in minerals of bone.
\end{abstract}

Keywords: Omega-3, bone resorption, high dose, bone ash.

\section{تأثير الجرع الهالية من الأحماض الهنية الوميكا -3 عل ليض عالم إنلث الجرذل البالغة}

\section{المالغص}

لجريت هذه الدرلسة لمعرفة تأثير الجرع العالية من الاحماض الدهنية أوميكا -3 في اليض الظلم

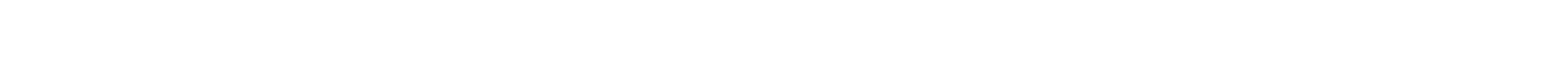

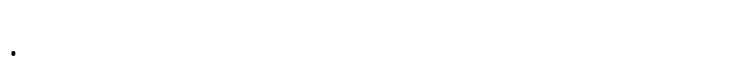


لأستخمت في هذه الدرلسة (20) أنث من إنث الجرذان الني تراومت أعمارهن (2.5 -3) ألثد هر ألثر

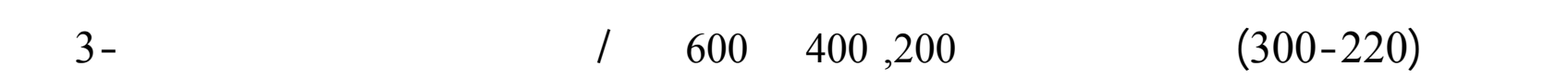

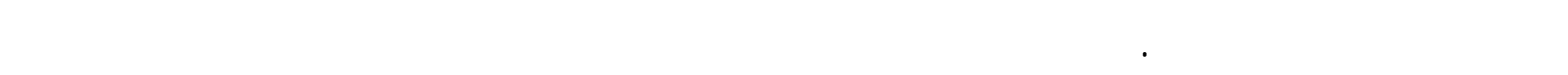

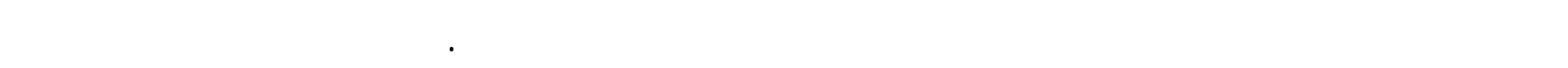

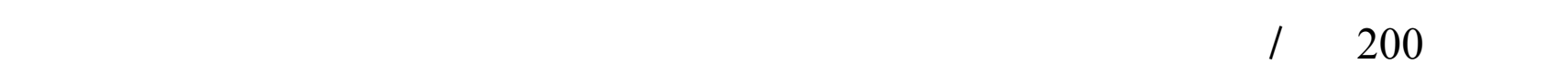

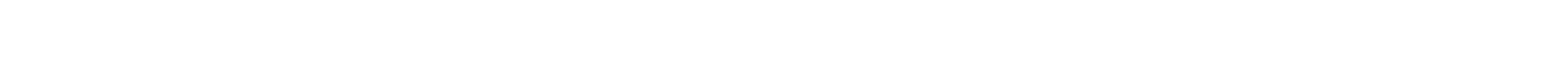

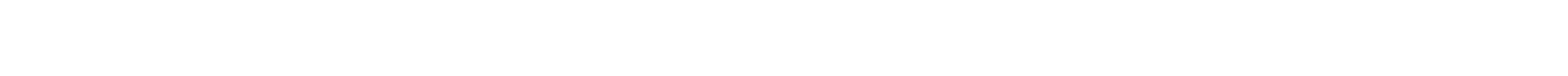

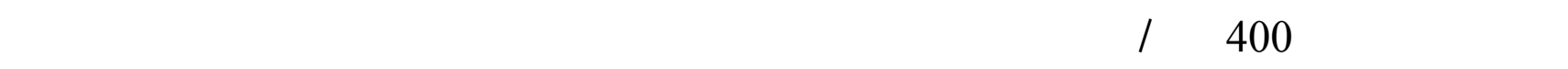

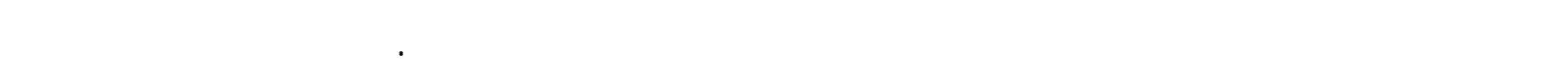

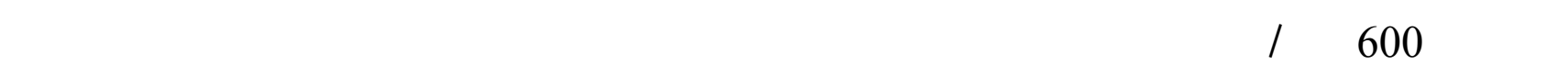

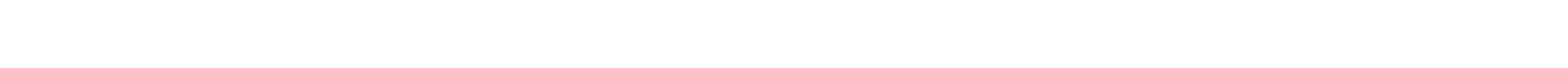

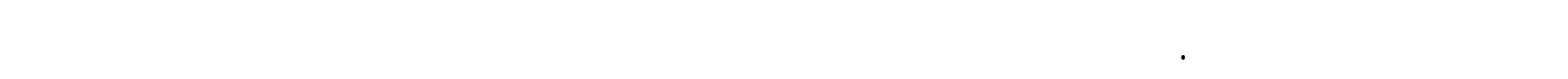

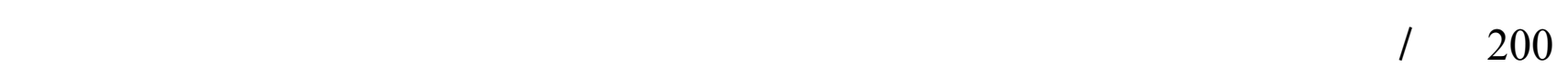

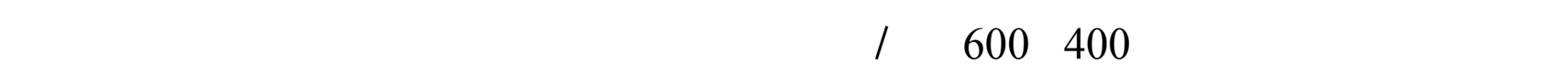

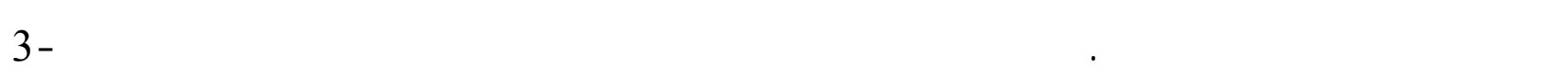
تؤدي إلى ارتشف الغم وحصول عدم توازن في مستوى العناصر المكونة له. الكامل الدالة: أوميكا -3، ارتشف الظم، الجرعة العالية، رماد الظم.

\section{INTRODUCTION}

Recently, many studies emphasize on the importance of omega-3 fatty acids in the treatment and prevention of many diseases. The doctors prescribed omega- 3 fatty acids and people used it in large spectrum without care to their side effects, especially on the bone.

The essential fatty acid is a type of fat that, the body cannot produce itself but must be received via dietary sources. There are two classes of essential fatty acids omega-3 and omega-6 (El-Khayat et al., 2010). Omega-3 fatty acids or $\omega-3$ fatty acids are family of unsaturated fatty acids that have a final carbon- carbon double bond in the 3-position, that is the third bond from the methyl end of the fatty acid. Important nutritionally essential $\omega-3$ fatty acids are $\alpha$-linolenic acid (ALA), eicosapentanoic acid (EPA) and decosahexaenoic acid (DHA), all of which are polyunsaturated (Simopoulos,1999). Polyunsaturated fatty acids are incorporated into cellular membranes in the body and its composition plays a key role in the behavior of the membrane proteins cell-cell communication (Albertazzi and Coupland, 2002). In observational and experimental studies, higher intakes of $\omega-3$ fatty acids appear to reduce the risk of coronary artery disease, hypertension, type 2 diabetes and cancer (Simopoulos,1999). Dietary fish oil has been demonstrated to protect against infection with numerous extracellular bacterial pathogens, regulate serum triglycerides and 
cholesterol levels. These effects have been proposed to account for the potent antiinflammatory properties of omega-3 fatty acids (Alam et al., 1991; Blok et al., 1992). Omega-3 fatty acids have been shown to inhibit the activity of the osteoclasts (Griel et al., 2007). Subsequently, it was shown that omega-3 fatty acids deficiency caused severe osteoporosis in rats. Further, when deficient animals were replenished with omega-3 fatty acids, the ratio of omega- 3 to omega- 6 fatty acids in bone compartments was reversed (Reinwald et al., 2004). A recent review concluded that most animal studies confirm the beneficial effects of omega-3 fatty acids on bone health, with many differences in study design, types and doses (Salari et al., 2008) but, there is no study about the effect of high doses of omega-3 fatty acids, therefore, this study aimed to evaluate the effect of different doses of omega-3 fatty acids supplementation on bone metabolism.

\section{Laboratory animals}

\section{MATERIALS AND METHODS}

Twenty adult female albino rats (2.5-3 months old, weighting 220-300 g) were maintained under conditions of controlled temperature $22-25^{\circ} \mathrm{C}, 12 \mathrm{~h}$ light-dark cycle in animals house of veterinary college of Mosul University. The animals were divided randomly into four groups, each group was housed in communal cage, water in polyethylene bottle was available as drinking water. Animals in each group received once daily for 30 days (oral administration) the following:

Group (1): Drinking water with standard diet (control).

Group (2): $200 \mathrm{mg}$ omega -3/kg with standard diet.

Group (3): $400 \mathrm{mg}$ omega -3/kg with standard diet.

Group (4): $600 \mathrm{mg}$ omega -3/kg with standard diet.

The animals were weighted weekly and blood was collected at the end of the treatment for the determination of biochemical parameters. At the end of treatment (30 days) the animals were anesthetized by diethylether and sacrificed. Right femur was taken for $(\mathrm{Ca}, \mathrm{Mg}$ and P) analysis in bone ash and left femur was taken for bone histopathology.

\section{Blood collection}

Blood samples were collected from female rats in the limited periods for each group from the optical vein (Madway et al., 1969) using capillary heparinized tube, Serum was separated and stored at $(-18){ }^{\circ} \mathrm{C}$ for biochemical measurements.

\section{Biochemical tests}

Serum alkaline phosphatase (ALP) activity was measured by spectrophotometric procedure using kit manufactured by (Biomerieux) which depend on the method of Belfeld and Goldbery (1971). Serum total calcium was determined using standard colorimetric methods with commercial kit manufactured by (Biolabo-france). Serum inorganic phosphorus was determined using standard colorimetric method with commercial kit manufactured by (Biolabo-france). The phosphomolybdate complex formed was measured at $(710 \mathrm{~nm})$. Serum magnesium was determined using standard colorimetric method with commercial kit manufactured by (Biolabo-france). Magnesium in serum reacts with xylidyl blue to form complex that was measured at $(530 \mathrm{~nm})$. Albumin concentration was determined using standard colorimetric method with commercial kit manufactured by (Biolabo-france) (Bishop et al., 2005). 


\section{Determination of Calcium, Magnesium and Phosphorous in bone ash}

Calcium, magnesium and phosphorous were determined in right femoral bone ash after the following were done: The femoral bones were carefully removed at necropsy, these bones were freed from soft tissue, weighed and ashed in (Muffle furnace) at $(600){ }^{\circ} \mathrm{C}$ for two hours. The ashed samples were extracted with Conc. $\mathrm{HCl}$, then diluted to $100 \mathrm{ml}$ by deionized water. Then magnesium was determined by Eriochrome Blank T method (Snell, 1981), and calcium was determined by Ca-EDTA. and phosphorous was determined by the method which depends on the reaction of inorganic phosphorous with molybdic acid to form yellow phosphomolybdic acid which is reduced to give a blue color (Bishop et al., 2005).

\section{Histopathological part}

The rats were dissected and the excised femurs were cleaned from the surrounding musculature and fixed with $10 \%$ formaldehyde in phosphate-buffered solution for 18 hours, followed by decalcification, then dehydrated in alcohol, cleared in xylene, and embedded in paraffin and they were cut into $5 \mu \mathrm{m}$ (thickness) and stained with hematoxylin and eosin (Tsuang et al., 2008).

\section{Statistical Analysis}

Statistical analysis was formed by sigma state 3.5. All data are expressed as means \pm S.E. The one way analysis of variance (ANOVA) tests were used for comparisons between all groups within probability $(\mathrm{p} \leq 0.001)$ (Steel and Torie,1980).

\section{RESULTS AND DISCUSSION}

The result in Table (1) and (2) showed that there is a significant decrease $(p \leq 0.001)$ in serum alkaline phosphatase activity in group that were treated with $200 \mathrm{mg} / \mathrm{kg}$ of omega-3 fatty acids compared with control group, which are accompanied with a significant increase $(p \leq 0.001)$ in serum calcium and phosphorus, also with a significant decrease $(p \leq 0.001)$ in the percentage of calcium and phosphorus and an increase in the percentage of magnesium in bone ash compared with control group. These results disagree with Das (2000) who reported that fatty acids are involved in calcium metabolism and high doses of omega- 3 fatty acids intake or lower ratios of n-6/n-3 fatty acids have been shown to increase calcium absorption, decrease calcium loss and increase calcium absorption in bone, so improve bone strength. In our study, the total alkaline phosphatase in serum was significant elevated $(\mathrm{p} \leq 0.001)$ after treatment with 400 and $600 \mathrm{mg} / \mathrm{kg}$ of omega-3 compared with control group, although the elevation in the group that were treated with $400 \mathrm{mg} / \mathrm{kg}$ accompanied with a significant increase $(\mathrm{p} \leq 0.001)$ in serum calcium and phosphorus, and a reduction $(\mathrm{p} \leq 0.001)$ in the percentage of calcium and magnesium and an elevation in the percentage of phosphorus in bone ash compared with control group and the group that were treated with $200 \mathrm{mg} / \mathrm{kg}$ of omega-3. On other hand, the elevation in serum activity of total alkaline phosphatase in group that were treated with $600 \mathrm{mg} / \mathrm{kg}$ accompanied with a significant reduction $(\mathrm{p} \leq 0.001)$ in serum and bone ash calcium and phosphorus with a significant elevation $(\mathrm{p} \leq 0.001)$ in percentage of magnesium in bone ash compared with control group and the group that were treated with $200 \mathrm{mg} / \mathrm{kg}$ of omega-3. The elevation in serum alkaline phosphatase activity and imbalance in mineral content calcium, phosphorus and magnesium of bone ash in the group that were treated with $600 \mathrm{mg} / \mathrm{kg}$ of omega-3 refers to an increase in bone resorption, since high alkaline phosphatase activity may be associated with a high 
turnover rate of bone (Garnero et al., 1994) which enhanced bone destruction and results in a slight rise in serum calcium, which in turn causes a compensatory reduction in parathyroid hormone (PTH) level (Schaffer and Gregory,1972). Serum alkaline phosphatase activity is an indicator of osteoblast activity in bone and marker of bone formation (Yilmaz et al., 2006). The elevation in serum alkaline phosphatase activity in this study agrees with (Sozer et al., 2006) who showed that there was an increase in serum alkaline phosphatase activity in ovariectomized rats because of the resorption of bone by estrogen deficiency. Alkaline phosphatase activity in bone reflects the activity of osteoblast and this enzyme is involved in the formation and mineralization of bone matrix (Leung et al.,1993). The elevation in serum alkaline phosphatase activity and reduction of percentage of calcium in bone ash in our study agree with Li et al., (2009) who reported that ovariectomy (increase bone resorption) induced high bone turnover in rats and increased alkaline phosphatase activity. Matrix degradation requires adhesion of osteoclast to bone an integrin alpha beta 3mediated event that also stimulates signals which polarize the cell and secrete resorptive molecules such as hydrochloric acid and acidic protease (Teitelbaum, 2005). Our study showed a significant decrease $(\mathrm{p} \leq 0.001)$ in serum calcium and phosphorus after treatment with high doses of omega-3 (600 mg/kg) which were accompanied with decrease in percentage of calcium and phosphorus in bone ash of the right femur, but an increase in percentage of magnesium in bone ash. This study agrees with Reddy and Lakshmana, (2006) who showed that there was a significant decrease $(p \leq 0.001)$ in serum calcium and phosphorus in bone ash of ovariectomized rats compared with control group. In the same time, treating the rats with $400 \mathrm{mg} / \mathrm{kg}$ of omega-3 results in a significant decrease in the percentage of magnesium and calcium in bone ash. This means that this dose affected bone resorption, this result agrees with Reginster et al., (1989) who observed a significant reduction in serum magnesium, red blood cell magnesium concentration and bone magnesium content in postmenopausal osteoporosis. The high concentration of omega-3 may decrease bone formation and secretion of hormones that stimulates osteoblasts activity or may elevate serum levels of neuropeptides such as substance P and calcitonin gene related protein (Rude et al.,1999).

Table 1: Effect of different doses of omega-3 on serum ALP activity, Ca, P and Mg

\begin{tabular}{|l|l|l|l|l|}
\hline & ALP U/L & Ca mg/dl & P mg/dl & Mg mg/dl \\
\hline Control & $86.12 \pm 1.946$ & $8.71 \pm 0.33$ & $4.42 \pm 0.067$ & $2.07 \pm 0.038$ \\
& A & A & A & A \\
\hline $\mathbf{2 0 0} \mathbf{~ m g / k g}$ & $85.15 \pm 1.488$ & $10.31 \pm 0.489$ & $5.32 \pm 0.184$ & $1.88 \pm 0.076$ \\
& B & B & B & A \\
\hline $\mathbf{4 0 0} \mathbf{~ m g / ~} \mathbf{~ k g}$ & $91.38 \pm 2.044$ & $10.97 \pm 0.490$ & $4.77 \pm 0.031$ & $2.16 \pm 0.021$ \\
& $\mathrm{C}$ & $\mathrm{C}$ & $\mathrm{C}$ & $\mathrm{A}$ \\
\hline $\mathbf{6 0 0} \mathbf{~} \mathbf{~ g} / \mathbf{~ k g}$ & $89.04 \pm 3.271$ & $8.24 \pm 0.454$ & $4.36 \pm 0.043$ & $2.04 \pm 0.025$ \\
& $\mathrm{D}$ & $\mathrm{D}$ & $\mathrm{D}$ & $\mathrm{A}$ \\
\hline
\end{tabular}

The values represent the mean \pm standard error for 5 animals/group.

A, B, C, D different vertical mean a significant variance. 
Table 2 : Mineral contents of bone ash of right femur from studied groups

\begin{tabular}{|l|l|l|l|}
\hline & percentage Ca & Percentage P & Percentage Mg \\
\hline \multirow{2}{*}{ Control } & $38.94 \pm 0.145$ & $10.15 \pm 0.265$ & $0.75 \pm 0.035$ \\
& A & A & A \\
\hline \multirow{2}{*}{$\mathbf{2 0 0} \mathbf{~} \mathbf{g} / \mathbf{k g}$} & $37.95 \pm 0.234$ & $9.86 \pm 0.171$ & $0.77 \pm 0.045$ \\
& B & B & B \\
\hline \multirow{2}{*}{$\mathbf{4 0 0} \mathbf{~} \mathbf{g} / \mathbf{k g}$} & $32.28 \pm 0.307$ & $15.69 \pm 0.519$ & $0.55 \pm 0.017$ \\
& C & C & C \\
\hline \multirow{6}{*}{$\mathbf{~} \mathbf{m g} / \mathbf{k g}$} & $35.31 \pm 0.475$ & $8.98 \pm 0.0918$ & $0.90 \pm 0.041$ \\
& D & D & D \\
\hline
\end{tabular}

The values represent the mean \pm standard error for 5 animals/group.

A, B, C, D different vertical mean a significant variance.

The results in Fig. (1) demonstrated the effect of $200 \mathrm{mg} / \mathrm{kg}$ of omega-3 on the histological examination of left femur and showed the clarity and quantity of osteogenic tissue between bony tissue, also there is a number of osteoblasts. In addition to the appearance of bony tissue more thickness in this treatment compared with groups that are treated with 400 and $600 \mathrm{mg} / \mathrm{kg}$. This result agrees with Miriam et al., (2009) who reported that $160 \mathrm{mg} / \mathrm{kg}$ of omega -3 fatty acids prevented osteoporotic changes in ovariectomized rats. Also the result agrees with Das (2000) who found animals fed long-chain omega-3 fatty acids tended to show an increase in bone formation also agree with El-khayat et al., (2010) who found an inhibitory effect of omega-3 fatty acids on bone resorption. A recent study with intact female mice indicates that long- term intake of omega-3 fatty acids, especially EPA, improve structural and mechanical properties of cortical bone in the femur, without detectable effects on age-related loss of trabecular bone or bone mineral density (Bonnet and Rferrari, 2009), since many studies of them (Sun et al., 2003) reported that polyunsaturated free fatty acids supplements enhanced calcium transport, improve BMD and prevent osteoporosis. Other researches mainly on animals also suggest its role in bone health (Weiss et al., 2005). The results in Fig. (2) and Fig. (3) showed that the treatment of rats with 400 and $600 \mathrm{mg} / \mathrm{kg}$ of omega-3 fatty acids leads to reduce in the thickness of bony tissue and reduce in the number of osteoblasts with clarity the osteoclasts and osteocytes, in addition to reduce the amount of osteogenic tissue. This explains the effect of high doses of omega-3 on bone. Three animals studies showed the adverse effects or no effect of omega- 3 fatty acids or a low ratio of omega-6/ omega-3 fatty acids on bone in growing rats (Claassen et al.,1995), pigs (Judex et al., 2000), and rabbits (Weiler and Fitzapatrick-Wong, 2002). Our study suggests that higher doses of omega-3 fatty acids have a negative effect on bone metabolism by decreasing the percentage of calcium in bone ash, therefore, they have a resorptive activity, calcium and phosphorus are two minerals essential for bone formation and their levels indirectly reflect bone metabolism. Our study suggests that higher doses of omega-3 fatty acids have a negative effect on bone composition and increase bone resorption. 


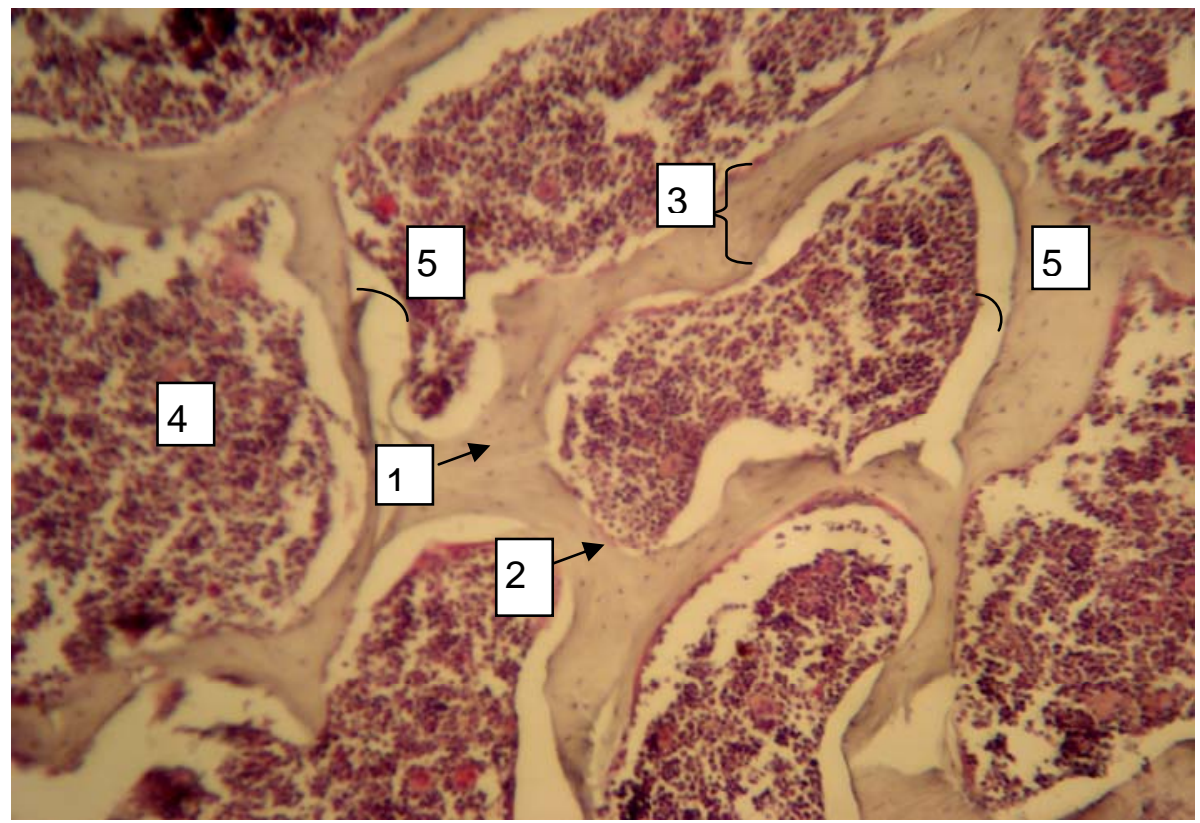

Fig. 1: Microsection of rat femur bone of group treated with $200 \mathrm{mg} / \mathrm{kg}$ shows (1) osteoblasts, (2) osteocytes, (3) quantity of bony tissue (thickness), (4) quantity of osteogenic tissue, (5) regular vacuole between bony tissue and osteogenic tissue, $\mathrm{H} \& \mathbf{E}(650 \mathrm{X})$

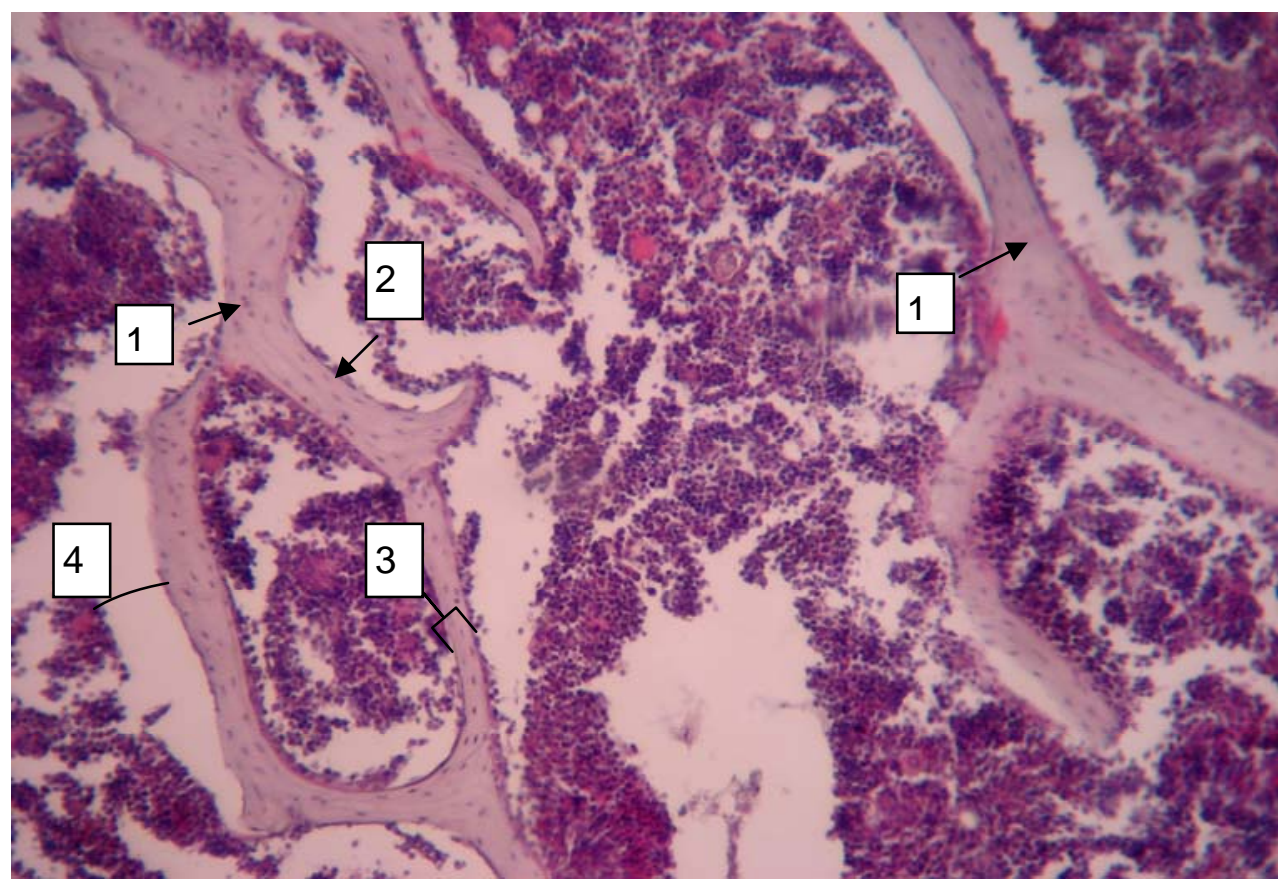

Fig. 2: Microsection of rat femur bone of group treated by $400 \mathrm{mg} / \mathrm{kg}$ shows (1) osteoblasts, (2) osteocytes, (3) little of thickness of bony tissue, (4) width vacuole between bony tissue and osteogenic tissue, $\mathrm{H} \& \mathrm{E}(650 \mathrm{X})$ 


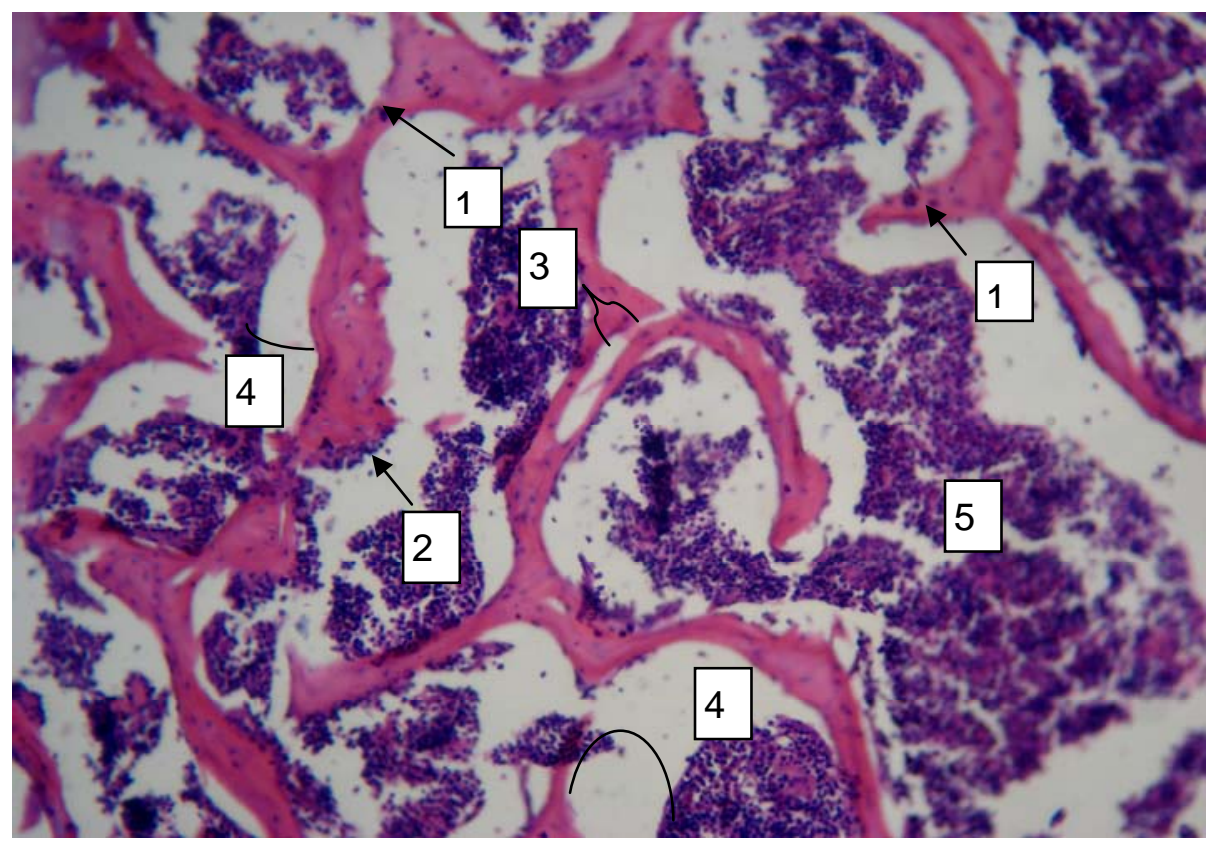

Fig. 3: Microsection of rat femur bone of group treated by $600 \mathrm{mg} / \mathrm{kg}$ shows (1) osteoclasts, (2) osteocytes, (3) little of thickness of bony tissue, (4) width vacuole between bony tissue and osteogenic tissue, (5) little of osteogenic tissue, $H \& E(650 X)$

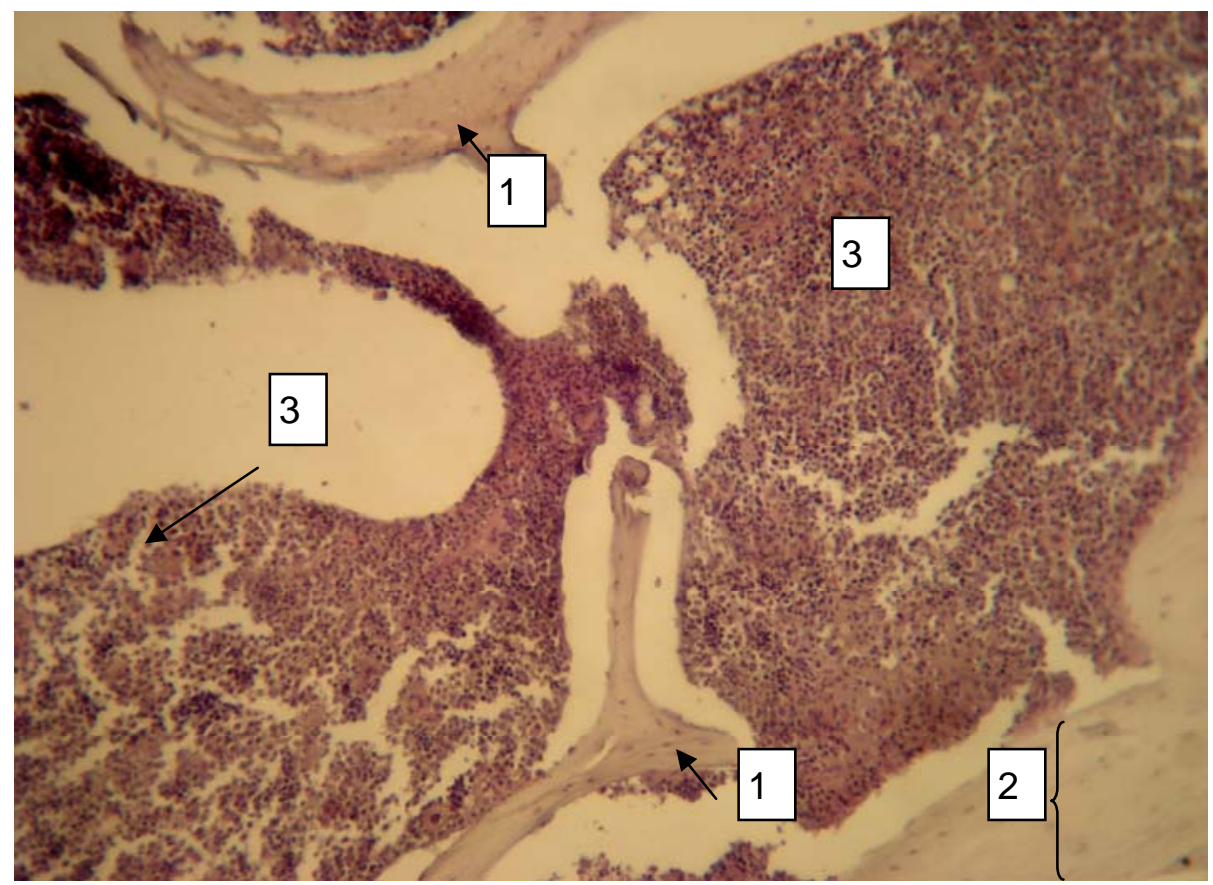

Fig. 4 : Microsection of rat femur bone of group of control shows (1) osteoblasts, (2) quantity of thickness of bony tissue, (3) quantity of osteogenic tissue, H\&E(650X) 


\section{REFERENCES}

Alam, S.Q.; Bergens, B.M.; Alam, B.S.(1991). Arachidonic acids, prostaglandin $\mathrm{E}_{2}$ and leukotriene $\mathrm{C}_{4}$ levels in gingival and submandibular salivary glands of rats fed diets containing n-3 fatty acids. Lipids., 26, 890-900.

Albertazzi, P.; Coupland, K. (2002). Polyunsaturated fatty acids. Is there a role in postmenopausal osteoporosis prevention?. Maturitas., 42,13-22.

Belfeld, A. ; Goldbery, D.M. (1971). Revised assay for serum phenylphosphatase activity using 4-amino-antipyrine. Enzyme., 12,561-562.

Bishop, M.; Duben, J.; Fody, E. (2005). "Clinical Chemistry". 4th ed., Lipincott Willimans and Wilkins, Philadalphia. pp.662-673.

Blok, W.L.; Vogels, M.T. ; Curfs, J.H.; Eling, W.M.; Buurman, W.A. ; Van der Meer, J.W. (1992). Supplementation in experimental Gram-negative infection and in cerebral malaria in mice. J. Infect. Dis., 165,898-903.

Bonnet, N. ; Rferrari, S. (2009). A long-term diet enriched in omega -3 fatty acids improves cortical bone structure and mechanical properties in mice. New frontiers in skeletal rese arch. Bone, fat and brain connections, Bethesda (abstract).

Claassen, N. ; Coetzer, H. ; Steinmann, C.M.; Kruger, M.C. (1995). The effect of different n6/n-3 essential fatty acids ratios on calcium balance and bone in rats. Prostagland. Leukot. essential fatty acids, 53(1),3-9.

Das, U.N. (2000). Essential fatty acids and osteoporosis. Nutrition., 16(5),386-390.

El-khayat, Z.; Rasheed, W.I.; Elias, T.R.; Hussein, J.; Oraby, F.; Badawi, M. ; Salem, S. (2010). Protective effect of either dietary or pharmaceutical n-3 fatty acids on bone loss in ovariectomized rats. Maced. J. Med. Sci., 15; 3(1), 9-16.

Garnero, P.; Vass, V.; Bertholin, A.; Riou, J.P.; Delman, P.D. (1994). Markers of bone turnover in hyperthyroidism and the effect of treatment. J. Clin. Endocrinol. Metab., 78, 955-959.

Griel, A.E.; Kris-Etherton, P.M.; Hilpert, K. F. (2007). An increase in dietary n-3 fatty acids decrease a marker of bone resorption in humane. Nut. J. 6:2 doil;10.1186/14752891-6-2.

Judex, S. ; Wohl, G.R.; Wolff, R.B.; Leng, W.; Gillis, A.M.; Zernicke, R.F. (2000). Dietary fish oil supplementation adversely affects cortical bone morphology and biomechanics in growing rabbits. Calcif. Tis. Int., 66,443-8.

Leung, K.S.; Fung, K.P.; Sher, A.H.; Li, C.K.; Lee, K.M. (1993). Plsma bone-specific alkaline phosphatase as an indicator of osterblastic activity. Bone and Joint Surg. Brit., 75-B(2), 288-292.

Li, N.; Qin, L; Han, T.; Zhang, H. (2009). Inhibitory effects of Morinda officinalis_extract on bone loss in ovariectomized rats. Molecules., 14, 2049-2061.

Madway, W.; Prier, L.E.; Wikinson, J.S. (1969). "A Text Book of Veterinary Clinical Pathology". The Williams and Wiking Co. Baltimore. pp.557-564.

Miriam, N.; Rosa, M. A.; Sarahi, M.; Maikel, V.; E dy, G. (2009). Effect of D- 003 a mixture of high- molecular weight aliphatic acids from sugarcane wax, and omega 3 fatty acids on bone of ovariectomized rats. Lat. Am. Pharm., 28(5),728-33.

Reddy, P.N.; Lakshmana, M. (2006). Withania Somnifera improve bone calcification in calcium deficient ovariectomized rats. J. of Pharm. and Pharmacology., 58(4), 513-519. 
Reginster, J.Y.; Strause, D.R.; Lecart, M.P.; Saltman, P.; Franchimont, P. (1989). Preliminary report of decrease serum magnesium in postmenopausal osteoporosis. Magnesium., 8,106-109.

Reinwald, S.; Li, Y.; Moriguchi, T.; Salem, N.; Watkins, B.A. (2004). Repletion with (n-3) fatty acids reverses bone structural deficits in (n-3) deficient rats. J. Nutr., 134, 388-94.

Rude, R.K.; Kirchen, M.E.; Gruber, H.E.; Meyer, M.H.; Luck, J.S. ; Crawford, D.L. (1999). Magnesium deficiency-induced osteoporosis in the rat: uncoupling of bone formation and resorption. Magnesium Res., 12(4), 257-267.

Salari, P.; Rezaie, A.; Larijani, B.; Abdollahi, M. (2008). A systematic review of the imbact of n-3 fatty acids in bone health and osteoporosis. Med. Sci. Monit. 14, 37- 44.

Schaffer, R.B.; Gregory, D.H. (1972). Calcium malabsorption in hyperthyroidism, Gastroenterology, 63, 235-239.

Simopoulos, A.P. (1999). Essential fatty acids in health and chronic disease. Am. J. Clin. Nutr., 70 (suppl), 560S-9S (abstract).

Snell, F.D. (1981). "Photometric and Fluorometric Methods of Analysis Metals". John Wiley and Son, NewYork, pp.531-537.

Sozer, V.; Uzum, H.; Guner, I.; Aydin, S.; Simsek, G. (2006). Bone metabolism ovariectomized rats with induced hyperthyroidism: the effect of estrogen replacement. Chinese J. Physiol., 49(6), 335-341.

Steel, R.G.; Torie, J. H. (1980). "Principle and Procedures of Statistics". 2nd ed. Mc GrawHill Book Co. Inc., New York. pp.540-548.

Sun, D.; Krishnan, A.; Zaman, K. (2003). Dietary n-3 fatty acids decrease osteoclastogenesis and loss of bone mass in ovariectomized mice. J. Bone Miner Res., 18(7), 1206-16.

Teitelbaum, S.L. (2005). Alpha beta 3 and macrophage colong-stimulating factor: partners in osteoclast biology. Immunol. Rev., 208, 88-105.

Tsuang, Y.H.; Chen, L.T.; Chiany, C.J.; Wu, L.C.; Chiany Y.; Sun J.S.; Wang, C.C. (2008). Isoflavones prevent bone loss following ovariectomy in young adult rats. $J$. Orthopaedic Surg. and Res., 3,12.

Weiler, H.A.; Fitzapatrick-Wong, S.C. (2002). Modulation of essential (n-6): (n-3) fatty acids ratios alters fatty acids status but not bone mass in piglets. J. Nutr., 132, 26672672.

Weiss, L.A.; Barrtt-Connor, E.; Vonmuhley, D. (2005). Ratio of n-6 to n-3 fatty acids and bone mineral density in older adults: the Rancho Bernardo study. Am. J. Cli. Nut., 81(4), 934-938.

Yilmaz, B.; Seyran, A.D.; Aandal, S.; Aydin, M.; Colakoglu, N.; Carpenter, D.O. (2006). Modulatory effects of aroclors 1221 and 1254 on bone turnover and vertebral histology in intact and ovariectomized rats. Toxicol. Lett., 166, 276-284. 